\title{
Islamic Authority: A Matter of Guardianship
}

\author{
By Abdullah F. Alrebh*
}

\begin{abstract}
In modern Western political philosophy, "sovereign authority" is central to statehood, and yet it has confounded politicians, pundits, and clerics worldwide. Nevertheless, understanding sovereignty is essential in understanding authority. This paper focuses upon issues of sovereignty and authority in contemporary Muslim society, while bearing in mind the common operational definitions concerning such notions as statehood, authority, and sovereignty itself may be problematic between the West and Middle East. It is thus an attempt to understand political philosophy in the Middle East in a different way than typically found in Western philosophy. Indeed, one may even argue "democracy" has no place in Islamic heritage, but is rather a contemporary matter for Islamic jurisprudence. The foundation of Saudi Arabia in 1932 as a traditional Sunni Muslim kingdom and the Iranian revolution 1979 that brought the Shia Ayatollahs to leadership roles, offer two models of Islamic theocracy, as well as Islam's involvement in shaping the region's political culture. At this point, one may ask if there is any validity of Western terminology in studying an Islamic state. One may also ask of the role of national history in Saudi Arabia and Iran in terms of "democracy" and "Shura".
\end{abstract}

Keywords: Secularism, Sovereignty, Theocracy, Vilayat-e Faqih, Wahhabism.

\section{Introduction}

Seyyed Hossein Nasr states plainly: "Today there is much talk of Islam and democracy" (Nasr 2009: 150). ${ }^{1}$ The study of religion versus secularization has been a hot button topic for many social scientists for decades. To keep matters manageable, we may think of a theocracy as a state with a particular religious doctrine governed by laws directly administered by a priestly order claiming divine commission; and secularism (as established in western industrial societies) as a system of privatized religion - setting rational norms and laws to govern society, utterly underplaying any influence of religion on governmental policy.

The primary concern of this paper is the continuum between the sacred and secular of political affairs in Muslim nations, focusing on two Middle Eastern countries often identified as having "Islamic rulers" (Bhargava and Acharya 2008: 283-284). The paper examines the origins of the contemporary political systems in Saudi Arabia and Iran and identifies the historical and theological legitimacy of each political system that establishes them as "Islamic states."

\footnotetext{
* Assistant Professor of Sociology, Grand Valley State University, USA.

${ }^{1}$ Raghid El-Solh (1993) identifies three attitudes toward democracy:

1. A foreign concept imposed by secular westerns.

2. A compatible concept with Islam.

3. A concept depends on its representative forms.
} 
These waters are entered with the admonition from Bernard Lewis (2010: 55) firmly in mind:

"... of all the non-Western civilizations in the world, Islam offers the best prospects for Western-style democracy. Historically, culturally, religiously, it is the closest to the West, sharing much — though by no means all —of the Judeo-Christian and Greco-Roman heritage that helped to form our modern civilization. From a political perspective, however, Islam seems to offer the worst prospects for liberal democracy."

For the present purposes, "theocracy" shall specifically refer to the establishment of religion as the source of norms and laws and "secularization" will refer to non-religious forces having an increasing influence over the operation of society (thus an ideal type of a secular society would be one devoid of any religious influence in matters of the state). ${ }^{2}$ In this regard, it worth noting "secularization" is not synonymous with "democracy", "freedom", or any similar modernist term. Indeed, some versions of secular society are potentially as restrictive and totalitarian as the strictest theocracy (e.g., the USSR or Maoist China); secularism is not a synonym for liberty.

From the Weberian perspective, rational-legal authority is favoured over the traditional and charismatic; thus, the functional/secular is preferred to the sacred/ theocratic. According to Thomas Luckmann (1979: 133)

"The 'secular' segments of the social structure developed pragmatic norms whose actual (or assumed) tendency toward 'functional rationality' justified the liberation of the institutional domains from the values embodied in the traditional sacred cosmos. Numerous, potentially competitive systems of ideas came into existence, each tied to a social basis of its own."

W. H. Swatos and Peter Kivisto (1998) inform us that Luckmann is among those who functionalize "secularization" to maintain rationality in modern institutions beyond the public sphere to include family and individuals. Therefore, Luckmann is perfectly correct when he states "religion is a private matter" (1979: 136) with both political and socio-psychological meanings in a secular society.

The development of sciences often reveals irrational superstitious norms ruling societies, some derived from religious beliefs. In this vein, Max Weber called such a process of cultural rationalization of societies the "disenchantment of the world" (Mills and Gerth 1958: 133). However, a theocracy relies on the cultural norms (i.e., religion), which derives its legitimacy from traditions and/ or charisma; clergy emphasize "rational" evidence for the validity of their beliefs.

\footnotetext{
${ }^{2}$ According to The New Dictionary of Cultural Literacy,

1. Theocracy: "A nation or state in which the clergy exercise political power, and which religious law is dominant over civil law" (2002: 327).

2. Secularization: "refers to the declining influence of religion and religious values within a given culture" (2002: 109).
} 
However, the validity of the religious beliefs is not of interest in this paper, nor is religion itself. Theocracy is a socio-political practice deriving its legitimacy from religion as a cultural tool. As such, it limits the masses' opportunity to alter these norms and laws as dealing with any challenge to dogma regarding Divine volition. For believers, a theocracy might well be considered to have a divine legitimacy. Thus, this paper rejects dealing with "religion", "religiosity", and "theocracy" as synonymous.

According to the Encyclopedia of Religion and Society, "[d]eclining religious authority allowed the development of functional rationality" (Swatos and Kivisto 1998: 453). In addition, C. Wright Mills (1958: 32-33) argues,

"[o]nce the world was filled with the sacred - in thought, practice, and institutional form. After the Reformation and the Renaissance, the forces of modernization swept across the globe and secularization, a corollary historical process, loosened the dominance of the sacred. In due course, the sacred shall disappear altogether except, possibly, in the private realm."

Indeed, secularization and religion are not truly comparable. Religion as belief, involves piety in practice. On the other hand, secularization involves a principle of the separation of religious institution and government institutions, emphasizing the privatization of religion. Thus, the discussion of the moment concerns secularism versus theocracy (rather than religion), as a theocratic government is pursuant to the doctrine of a particular religion as the source of socio-political norms. This clarification helps the reader to skip fruitless arguments presenting secularism as "anti-religion" or even "agnostic/atheist/anti-theist." Comparing theocracy with secularism is a socio-political matter, not a theological one, as religiosity is not equal with the religion itself. Religiosity is the human understanding of religion, as subject to error and accuracy.

This paper distinguishes the sacred from the secular in the state structure of Iran and Saudi Arabia, and links the contemporary sacred politics to the Islamic heritage based on the Sunni and Shia different interpretations of the legitimate leadership. The "theocracy" in this case refers to Sharia law. Alternately, "secularism" in predominantly Islamic nations recalls "irreligious", "modern" ways of thinking affecting Muslim societies, such as socialism, modernist liberalism, and nationalism. In this regard, Saudi Arabia and Iran are the best cases for studying the "theocracy" end of the continuum, as they apply Sharia as derived from Islamic text. Thus, readers need to be aware of the cultural and historical context of political authority in the Muslim world at the beginning of the $20^{\text {th }}$ century. This context takes a considerable part of this paper, as the whole debate of Islam and/versus democracy in general, in Saudi Arabia and Iran in particular is built on this context. 


\section{Terminology}

The term "sovereignty" as applied in Western social science scholarship does not exist in the Islamic literature. Instead, Hakimiah (the best translation is "governance") is the Islamic term means the right to rule and make laws. Abu Hamid al-Ghazali ${ }^{3}$ (1960) described Hakimiah as "obedience to Allah and obedience to those whose obedience is duty according to Allah" (c.f. Quran 4/59). Therefore, Allah is the source of Hakimiah; nobody enjoys it away from Him and everyone must obey Him as a duty. This naturally brings up the term wali al-amr - which means the "guardian" or Muslim religious ruler-whose authority in Muslim society is absolute. Thus, as the relationship between state and religion is concerned, Hakimiah supports the efforts of Islamic reformers advocating to revise constitutions, and aims to link the "nation state" with the "Islamic thoughts" (Oumlil 1985: 167-169).

Much like "sovereignty", the term "authority" in Western social science scholarship also has no place in Islamic literature. Similarly, the term $a m r^{4}$ may be a concern of translation issues, but generally refers to the governing of the Ummah. ${ }^{5}$ Thus, as mentioned above, the term wali al-amr means the Muslim religious ruler, and therefore these terms-Hakimiah and al-amr-are beyond mere "political structure", as they have been accepted as part of the adherent's daily religious beliefs. Thus, the applications of these terms differ according to various Muslim sects.

\section{The Bases of Authority in the Islamic Heritage}

While Shia Muslims believe in the divine assignment of the succession of the Prophet Muhammad, Sunni Muslims do not believe that God has chosen particular successors ("caliphs"). These theological interpretations explain much of the variation of the clergy's power upon the masses within each Islamic school. From the Shia perspective, the successors of the Prophet are the twelve Imams he listed in his Hadiths. ${ }^{6}$ The last Imam — named al-Mahdi- has been withdrawn

\footnotetext{
3 Also known as al-Imam Al-Ghazali $(1058$ - 1111). One of the most influential Muslim philosophers. Born in Persia and traveled to different Muslim cities such as Baghdad, Mecca, and Madinah.

${ }^{4}$ Approximate meanings to the Arabic word amr would include: order, ordinance, affair, decree, and instruction

5 The Arabic word meaning is "nation" or "community". For example, the term al-Ummah alIslamiah means the whole Muslim nations or communities in the global perspective. Similarly, alUmmah al-arabyah which means the entire Arab world.

${ }^{6}$ A historical note is necessary here. The majority of Shia identify with the "Twelvers", sharing most other Muslims' beliefs, though with some specific and significant differences. They believe in the "khalifa" or "caliph", which means the successor to the Prophet as appointed by God. Those successors are only Ali Bin Abi-Talib (the cousin of the Prophet Mohamed and his son of law, 599-661 AD) and 11 of his descendants; thus they are called "Twelvers", referring to the first 12 Imams. They look at those 12 Imams as sacred, infallible people selected by God Himself to take care of Islam after the prophet passed away. Furthermore, the last Imam, Al-
} 
by Allah "into a miraculous state of occultation (hiddenness) in 939 C.E." (Nasr 2007:67). He will remain in his occultation until Allah calls him again to come as the saviour ("messiah") of this world. According to the Shia literature, Al-Mahdi left a testament to his followers referring them to the religious scholar with the greatest knowledge of the religion. Thus, Shias believe in the clergy as the successors of their Imams. On the other hand, Sunnis do not believe in such divine assigning of rulers. They believe in the stability of Muslim nations under a single strong ruler, regardless of his level of religiosity. As long as he does not deny any principles of Islam, all Muslims — including the clergy — must obey him. Obeying the king put clergy in a position of playing a secondary role in politics and governance in Saudi Arabia, as their role is limited to legitimize the royal rule and interpret Sharia law (Al-Atawneh 2009).

Going back to the early history of Islam, right after the death of Prophet Mohammed (571-632 AD), a number of Muhammed's followers supported Ali Bin Abi-Talib to be the successor of the Prophet based on the Prophet's testament in Ghadir Khumm. ${ }^{7}$ Another group of followers were arguing about who should succeed the prophet, a man from Mecca "Muhajirun" or Madinah "Ansar, ${ }^{8}$ and both do not concern the mentioned testament. The second group reached their final decision and selected Abū Bakr aȘiddīq from Mecca as the first Caliph, and impose his authority as the guardian of Muslims. Since then, Sunni believe in the de facto rule; either through selection by circle of decisionmaking, ${ }^{9}$ or through appointment by the former ruler like what happen with the second Caliph Umar ibn Al-Khattāb who was appointed by Abū Bakr aṣ-Ṣiddīq. The de facto rule became a norm with the Umayyad Caliphate (661-744 AD) that became the first Muslim Monarchy.

The group that advocated for Ali Bin Abi-Talib still identify him as the legitimate successor of the Prophet, and consider those who proclaimed themselves Caliphs as non-legitimate rulers. Even when Ali was selected to be the forth Caliph (656-661 AD) based on Sunni norm, his adherent did not see this selection as a source of legitimacy, they argued that, he was finally got "his right" and led the Islamic state. However, some figures - who are well respected in the Sunni literature - fought Ali until they attained de facto rule and established their monarchy. Ali's eleven descendants enjoy — in Shia's mind - the same status of Ali as the legitimate guardians of Muslims. Basically, Shia believe that early

Mahdi (born $869 \mathrm{AD}$ ), was hidden by the order of God and is the messiah who will rid the world of injustice alongside Jesus.

${ }^{7}$ Ghadir Khumm is place where Prophet Muhammed gave a speech that considered by Shia the testament appointing Ali as his successor, while Sunni see this as no more that in a sign of high esteem and affection. Both sects recognize the verbal part of the Hadith, however, they interpret it in different ways. This story occurred 632 AD 3 months before Prophet Muhammed passed away.

${ }^{8}$ Mecca: The birthplace of Muhammed where he started his mission. The believers from Mecca who joined the Prophet Medina called Muhajirun, which means immigrants in Arabic. Madinah: The First capital of Islam, as Muhammed migrated to it escaping from Mecca elite who were anti-Islam. The believers from Medina who welcomed and supported the Prophet called Ansar, which means adherents in Arabic.

${ }^{9}$ In Arabic, Pronounce Ahl al-Hall wa al-Aqd, which means people who enjoy power within the nation and can affect the political decision. 
Muslims ignore the prophet's testament in Ghadir Khumm and let down the legitimate leader Ali, and then his 11 descendants, which is considered in the Shia perspective as denying the divine grace by rejecting the rightful Imams and Caliphs. Thus, from Shia perspective, the guardian of Muslims is the ideal man of piety and religious knowledge, and if he could not rule politically, good Muslims should stick to him to learn the true way of Islam until he - or one of his successors - get the political rule of the nation of Islam.

Here is the point; the bases of legitimacy of Sunni and Shia sects are different: the de facto ruler versus the pious teacher. Applying these bases in the modern history, the successors of the de facto ruler is the political leaders (i.e., monarchs and presidents) regardless of their piety levels. On the other hand, the successor of the pious teacher is the mullah "clergy" regardless of their political history and knowledge. Therefore, the clergy have the divine legitimacy as wali al-amr in Shia, while for the Sunni this legitimacy is reserved for the political ruler. ${ }^{10}$

Hassan al-Banna (n.d.) ${ }^{11}$ argues that the ideas of constitution and citizenship are coming from the core of Islam and are not derived from the West, predating the Western applications of these concepts by centuries. al-Banna avoided provocative terminology, such as describing non-Muslim citizens as ahl aldimmah, ${ }^{12}$ - which requires recognizing them as citizens rather than subject to the Islamic state. As a result of rising Islamic movements, some modern Muslim states added the declaration "Islam is the religion of the state" to their constitutions, or formally recognized Islam as one of their major sources of legislation (Jadaane 1979:137-138).

\section{Battling Secularism and Calling for Modernity}

Linking the terms "modernity" and "secularism" with "the West" recalls the colonial history of the Muslim world by the mostly "Christian" Western world. Indeed, the European colonization of the Middle East was beyond merely political-military control. Not surprisingly, such a negative history may easily create a wall of rejection of any Western cultural product for many Muslims; the best way to attack these concepts is linking them with the evil colonizer. Yusuf al-Qaradawi blames the Arab and Muslim ruling elites of the early twentieth century because they accepted the Western/Christian concept of

\footnotetext{
${ }^{10}$ According to S. H. Naser, 67:

The understanding of the term imam therefore differs greatly in Sunnism and Shi'ism. In Sunni Islam the term has many uses, but it is never used in the mystical and esoteric sense given to it in Shi'ism. In Shi'ism, the Imam, like the prophets, is inerrant ( $m a$ 's.um) and protected from sin by God. He possesses perfect knowledge of both the Law and the Way, both the outer and inner meaning of the Quran. He also possesses the power of initiation (walayah/wilayah) and is the spiritual guide par excellence, like the Sufi masters within their orders. In fact, the first eight Shi'ite Imams are also central spiritual authorities or poles of Sufism and appear in the initiatic chain of nearly every Sufi order.

11 An Egyptian scholar (1906-1949), the founder of the Muslim Brotherhood.

12 A fully "protected person" who may work and pay taxes, but is not obligated to Muslim civic duties.
} 
religion as "merely [the] relationship between man and God", supportive of the "evil colonial concept of the separation of state from religion" (al-Qaradawi 1971: 151).

Sayyid Qutb ${ }^{13}$ argues that religion and state are inseparable in Islam, as God is the only source of legislation (1992). Qutb supports that premise by arguing that letting people legislate by their collective minds gives them falsely divine roles. Abdulilah Belakziz argues Qutb's ideas are aimed at building a theocratic state that derives its legitimacy from religion rather than society. This is exactly what the modern Jihadi movements in the $20^{\text {th }}$ and $21^{\text {st }}$ centuries believed. Some scholars consider the modern laws as "infidel laws"; i.e., set by infidels who make Muslims follow them (Belakziz 2004: 210).

John Esposito (2011) discusses the Islamic attitude toward secularization from a very critical point. The conflation of concepts is shown below:

\section{Modernization $=$ Secularization $=$ Westernization $=$ Anti-religion}

This idea goes with "the confluence of religion, nationalism, ethnicity and tribalism in global politics in the post-Cold War ... [when] religion has been used to reinforce national identity" (Esposito and Tamimi 2000: 1). This view meshes well with claims made by the proponents of secularization to diminish the role of religion as they argue for "modern rationality, science, and the ideal of representative governments as sovereign, replace religion as a source of authority, regulation and security" (Bayat 2011: NP).

However, in the Middle East, independence movements used Islamic symbols supporting their demands for liberation from the colonial forces and their desire to establish modern Muslim states. The best example illustrating this is the Iranian Revolution of 1979, which switched a secular regime into a theocratic one. Post-1979 offers a tangible model of Theocratic-Islamic rule (Bayat 2011). Moreover, the Iranian Revolution was "a movement of the poor and marginalized" (Tamimi and Esposito 2000), which opened the door for an Islamic revival in the Muslim World. ${ }^{14}$ In contrast to that, the Islamic Salvation Front (FIS) in Algeria won the majority in municipal and parliamentary elections, while the Algerian army intervened to support the secular elites.

\footnotetext{
${ }^{13}$ Sayyid Qutb (1906-1966) an Egyptian Islamist theorist, poet, and the leading member of the Egyptian Muslim Brotherhood in the 1950s and 1960s. He published 24 books including his most popular books Social Justice and Ma'alim fi-l-Tariq. He is counted as one of the most radical members of the Muslim Brotherhood (see: Schneider and Silverman, 2006: 202, 266). He was executed by Nasser's regime in 1966.

${ }^{14}$ Many Islamists consider Western democracy as something similar to al-Shura ("consultation"). This similarity includes recognizing the sovereignty of the masses and their right to select rulers through free elections. According to Rashid al-Ghannushi, "democracy is the best development of human thinking ... and ... it should not be rejected due to its defects, because this would support dictatorships" (1993).
} 
"Thus, while it was believable to charge that the FIS was anti-democratic and that Islam (religion) and democracy were incompatible, the military's seizure of power and negation of free and fair elections to preserve a secular option was not accepted" (Tamimi and Esposito 2000:4).

Such action can be considered beyond "anti-religion" to be genuinely "antidemocratic" because the army effectively cancelled the election's result and denied the people's choices. (Vox Populi is not always popular with the ruling elites.) At this point, Islamists might argue that the Algerian case is an example of the "anti-religionist" Middle Eastern regimes that might call for maintaining secularism as the way for "protecting freedom" (e.g., Turkey, Egypt, and Tunisia). Same argument might be brought regarding the Egyptian coup in 2013 when the army overthrew the Muslim brotherhood (president and other political positions) who were elected in a democratic way.

Such actions against Islamist politicians might generate a resentment by the masses over secularism in general, leading in turn to what might be called "antisecularism" Islamic attitude. According to Fauzi Najjar, Muslims in Egypt view Western ideas as a threat to the Sharia law, noting that modernist writing in Egypt was started in the late $19^{\text {th }}$ century - mostly by Christian Syrian immigrants. On the other hand, some Islamic figures even argue that Islam is simply a religion and not a state (Najjar 1996).

Aziz al-Azmeh (2008) argues that secularism is a natural development of human history. It is an inevitable reality, even though political Islamists do not like it. The conflict between Islamists and secularists creates a compromising group wanting to satisfy Islamists and keeps the principles of secularism. According to al-Azmeh, such a compromise would not succeed.

Al-Azmeh's beliefs aside, the Islamic resurgence with its call for "return to Islam" or "Islam is the solution" (c.f. Tessler 2002: 340), enhanced the debate between the secularists and Islamists. In this regard, many of the Islamist figures consider secular thought as anti-Islam (e.g., Sayyid Qutb and al- Abul A'la Maududi ${ }^{15}$ ). The dangers of such fundamental Islamic attitudes appear as it charges modern society with kufr (infidelity), which forced some writers to shun the use of the term "secular", replacing it with "civil"-as in "civil society" or "state" (c.f., Asad 2003: 23). Both secularists and theocrats charged each other with an absence of constructive dialogue. Simply, secularists faced charges of being apostates of Islam and agents of Western powers and culture on one side, while Islamists faced charges of being backward-thinkers attempting to impose a way of life not applicable in the $20^{\text {th }}$ century on the other.

Beyond public conceptual misunderstanding, some scholars mislead their audience, especially when they discuss the linguistic background of the concepts. For example, Najjar argues the term almaniyya comes from the root $i l m$, which

\footnotetext{
${ }^{15}$ Abul A'la Maududi (1903-1979) Pakistani Muslim revivalist thinker and leader; the founder of Jamaat-e-Islami, the Islamic revivalist party in Pakistan. He published over 120 books. In his popular book The Islamic Law and Constitution (1955), he sets his conceptualization of the modern "Islamic state". He expressed his view of the Islamic State and applying of Sharia law in his book Islamic Way of Life (1948).
} 
means "science" or "knowledge," which absolutely fits with the Western term "secularization" (Najjar 1996: 2). However, some Islamists think the term would give the wrong impression, that science is "opposed to religion" (Najjar 1996: 2-3). The historical thinking behind this may be traced to the anti-religion regime founded in Turkey in 1924 by Ataturk, which led Islamists to mislabel and equate "secularization" as "atheism." The association between secularization and kufr is therefore a serious matter.

Muslim societies emphasize the cultural identity through the revival of religion. In this regard, Samuel Huntington argues the resurgence of Islam "embodies the acceptance of modernity, rejection of Western culture, and the recommitment to Islam as the guide to life in the modern world" (Huntington 1996: 110). Islam as a religion — and way of life — is the primary factor that distinguishes Muslim politics and society from others; thus, it is not surprising to find this "way of life" involved in the socio-political sphere. Huntington mentions some problems such as economic conditions, the large young populations, and the authoritarian regimes, which led to the resurgence of Islam in those societies which arguably led Muslims to distrust their secular regimes. Such regimes are, of course, mostly supported by Western powers and yet claim to believe in the popular phrase "Islam is the solution" ( $c f$., Najjar 1996:1, Tessler 2002: 340). The results of the "free" elections in post-Arab Spring Egypt and Tunisia are good evidence for this claim. Hoover (2011) like Huntington suggests that Islam becomes the particular focus after the end of the Cold War, as the conflicts with Western policies take place in Muslim lands.

\section{Protestant-Model of Reform}

According to Michaelle Browers and Charles Kurzman (2004), the enlightenment movements claims that religious studies have never resolved the tension between theological and non-theological approaches, which causesometimes - some theological appeals to the scientific standards. A good example here is the fatwa issued by Shaykh Bin Baz-the former Grand Mufti of Saudi Arabia - asserting that the earth is flat and disk-like and that the sun is revolving around it, as "the Transmitted and Sensory Proofs of the Rotation of the Sun and Stillness of the Earth" (Haddad 2015: 351). The theological authority of the clergy gives them the right to challenge the scientific facts without any basic background in the field. Kurzman and Browers cite Blunt who linked Wahhabism with Protestant Christianity in terms of religious reformation. According to Blunt, "just as the Lutheran reformation in Europe, though it failed to convert the Christian church, caused its real reform, so Wahhabism has produced a real desire for reform if not yet reform itself in Mussulmans [sic]" (Blunt 2013: 85). On the opposite view, Kurzman and Browers cite Wilson who argued, "just as the Protestant Reformation was followed by a counter-reformation in Roman 
Catholicism, so Wahhabism [sic] was the instrument for arousing Sunni Moslems" (Browers and Kurzman 2004: 2). ${ }^{16}$

Many Islamic reformers, both Sunni and Shia, ${ }^{17}$ advocate the Protestant (specifically Lutheran) model of religious reform. Scholars who link the revival of Islam with Christian Protestantism rely on the common beliefs between both religions such as asceticism, work ethic, and having religion as the moral + Yet, there is a long debate of which affects the other, Islamic civilization or the Western (mostly Christian) civilization. This debate relies on the historical account of the Islamic civilization, which is succeeded by the Western civilization. Indeed, many of those who discuss this issue ignore the fact that both Eastern/ Islamist and Western/Christianity had a role in leading the global civilization in different particular eras, and both mutually benefit each other. However, such a discussion is beyond the scope of this paper.

\section{Islamism vs. Secularism}

As mentioned earlier, the terms "authority" and "sovereignty" have no place in the Muslim sacred texts; rather, we find such other terms as "Hakimiah" and "amr". Islam is a religion with set of norms regarding the public sphere already in place. In fact, it is the Muslims' duty to make the world better. Ibn Khaldūn claims that "Islam is the only religion whose religious leaders involve politics and lead the nation, ... the person in charge of religious affairs in (other religious groups) is not concerned with power politics at all." (Ibn Khaldun 2005: 212-216, 1958: 473). Ibn Khaldūn compares Islam/Quran with Christianity/ Bible, and then concludes that: Islamic text includes law and path of rules, while Christian text merely focuses on stories and general ethics.

However, a short time after Prophet Muhammad passed away, his successors launched wars seeking the extension of their territories. Despite the long debates regarding the rightness or wrongness of these wars (debates which even many Muslims consider non-religious actions, merely territorial), the reality is that Islam was the religion of strong states. This was the case, at least, until 1922 when the Ottoman Empire in Turkey was abolished. During this long history, the theocratic philosophy of politics has grown in terms of the concepts of state and society, which of course, affects contemporary Muslim sociopolitical thought. So, it is not surprising to find secularization to be considered a significant challenge to religion in the contemporary era.

In the same manner of the Western misunderstanding of a number of Islamic concepts (e.g., "Islamist" = "fundamental Islamic jihadist"), I would argue the powerful reverse is equally clear-that many contemporary Islamic scholars misunderstand the various religious impacts of Western secularization. For

\footnotetext{
${ }^{16}$ See also Wilson, Samuel Graham. Modern movements among moslems. Fleming H. Revell Company, 1916.

${ }^{17}$ For example, Jamal al-Din al-Afghani, Habib Allah Pur-i Riza, Hadi Atlasi, Muhammed Rashid Rida, Tariq Ramadan, Ali Shari'ati. For further discussion, see Browers and Kurzman 2004.
} 
example, Mohammed Imara ${ }^{18}$ compares an ideal hypothetical Islam in the Middle East with the empirical secularization in Europe. Yet, it is inconsistent to deal with a certain sect - even if the largest one-and attempt to suggest it covers the entire religion; Imara needs to explicitly state whether he is considering Christianity (in general) or specifically Catholicism. In addition, comparing Islam (in general) with Catholicism as the reason for the Western notion of seeking a non-religious way of life reveals an ignorance of the diversity of concepts of Christianity and its many various sects, secularization, and Western society. For example, when discussing challenges to the Catholic church's authority in Europe, one needs to start with the Protestant movement as led by Martin Luther in 1517, who established a rational critique of the Catholic church, especially his strong rejection of selling "indulgences" as the way to gain pardon from God's punishment for sin. As the literature repeatedly shows, Martin Luther's Protestantism has had a great influence upon Western secularization in terms of criticizing the Catholic hierarchy that based on the theocracy.

Furthermore, Imara shows his ignorance of non-Sunni Islamic thought as he argues that only in Shia Islamic thought is the doctrinal authority of the clergy an accepted principle. Yet, in Sunni Islam, the doctrinal authority of the rulers is in just the same as with Shia; the only difference being that the Sunni ruler controls the Sunni clergy whom must obey him, as he is recognized as the guardian (wali al-amr). Imara further fails to define what he means by the "true Islam" he wants Muslims to turn to? He emphasizes the importance of the Islamic state without offering further details of his view of its structure.

Imara pursues the mixing of concepts. As he argues, Islam as a religion has a function in the state, but this does not mean the two are united and indistinguishable and thus the secularist fear of a theocracy is unjustified. This self-contradictory last sentence does not make sense! How might a secularist not worry about a theocracy when "a religion has a function in the state"? It is well known that the imposition of Sharia law is part of "the religionization of the society" (Souryal 1987: 429). Santi Rozario and Geoffrey Samuel present two examples of such theocratic tendency that target the entire society, (1) Egyptian Muslim Brotherhood who advocate to establish an Islamic state with Islamic law "Sharia", (2) Afghan Taliban who tend to enforce the moral and personal transformation of the behaviours of society members (Rozario and Samuel 2011).

Imara's point of view is in opposition to many secular thinkers who came from a Muslim background. For example, Halim Barakat argues, "religion - as concrete behaviour and defined in functional terms - seems to serve particularly as a mechanism of control, instigation, or reconciliation" (1993: 129). Furthermore, Barakat sets a progressive formula for a modern Arab society, including a fiveelement package: secularism, democracy, social justice, and unity with diversity (1993: 10-11). However, thinkers need to be clear in terms of what they mean

\footnotetext{
${ }^{18}$ Cited by Najjar, I have reviewed Imara's original text titled Secularism and our modern renaissance [Almaniyya wa Nahdatuna al-Haditha], Cairo: Dar al-Shoroq 1987.
} 
by secularism, does it mean equalizing individuals regardless of their religious background, or exclusion of religion? ${ }^{19}$

Muhammed A. al-Jabiri includes Michel Aflaq's view ${ }^{20}$ of secularization, as it is not anti-religion but rather a matter of equality among the citizens (alJabiri, 1992: 57-58). In addition, he emphasizes the nation state [secular regime] as best way of accomplishing "Arab Unity" (al-Jabiri, 1992: 63) considering democracy as the way of avoiding the ideological state-including so-called "Arabism" and "Islamism". In other words, Arab countries must respect the concept of state's sovereignty (Al-Jabiri 1992: 66-72).

While we may hypothesize a continuum with secularism on one end and theocracy on the other end, there is no need for a contradiction between secularism and faith. Rather, the problems become manifest when fanatics of either camp dominate the conversation. Note that most Muslim secularists are avowed believers in Islam and are proud of its cultural and moral legacy. While some may argue that there is no secularization in the Arab world, what happens is that some societies simply struggle to be civil states, religiously inclined or otherwise. Therefore, there are some important issues regarding accepting modernity without harming religion (e.g., prohibiting usury, women's issues).

\section{Islam and Democratic Reform}

Social scientists - from Weber, Comte, and Durkheim to Marx and Mills and beyond - have engaged in the debate of the sacred versus the secular. Universally among them, democracy is seen as a modern political value. Contradictorily, Islam is a religion that existed before modernist thought, and this is also applies to other faiths such as Judaism and Christianity. Thus, one does not expect to find a clear statement calling for democracy in such premodern religious texts. However, this does not mean Islam is contrary to democracy. Rather, the question is: as a religion, what is Islam's attitude toward democracy? The answer may not be as easy to discern as some Muslim states claim when adopting and practicing democracy. But again, the primary concern of this paper is the development of a continuum between a secularist society on one end of the spectrum and a theocracy on the other, with a focus on two Middle Eastern nations often identified as having "Islamic" rulers.

Islam "versus" democracy is one of the hot socio-political topics in terms of its ramifications. Muslims view their religion as a matter beyond simply being a set of beliefs; it is a way of life. Thus, it involves the political sphere as an ideology that is not necessary to convince everybody. When Mark Tessler says of the Islam/ democracy debate, "Islam plays a critical role in shaping political culture" (2002: 339 ) in the Middle East, he raises a question of how these countries should be

\footnotetext{
${ }^{19}$ According to The New Dictionary of Cultural Literacy, secular is "not concerned with religion or religious matters. Secular is the opposite of sacred. ... Secularisation refers to the declining influence of religion and relgious values within a given CULTRE". (2002:109).

${ }^{20}$ Michel Aflaq (1910-1989) is a modern Syrian philosopher and the founder of Ba'athism, which ruled in Syria and Iraq until 2003.
} 
governed. Such a debate expands the ideas brought by al-Jabiri who discussed the relations among national, religious, and transnational aspects of identity in the Arab world. In this respect, Tessler raises a point of how and who interprets the religion in order to come up with the political interpretation, as religion has been regularly utilized to justify rulers. Tessler demonstrates the relationship between religiosity and conservativeness, including the tendency of supporting the military or hawkish foreign policies.

Far from the idea of Islam as a political religion, Tessler (2002: 348) argues, "Islam appears to have less influence on political attitudes than is frequently suggested by students of Arab and Islamic society ... [and] there is most often no relationship between Islamic attachments and attitudes toward democracy." In addition, "whereas religiosity most often tends to push toward political conservatism in more secular societies, it does so less frequently and consistently in more religious societies" (Tessler 2002: 350). This may well lead one to conclude that-based on Tessler-religion affects politics in the Western World more than the Arab World. Tessler's conclusion meets with the historical facts brought by Albrecht and Schlumberger about the Protestant inspiration in the Islamic revival movements early of the $20^{\text {th }}$ century (Albrecht and Schlumberger 2004). In same manner of Norris and Inglehrt (2011) who argue that religious fundamentalists in Western societies have become more active rather than more numerous. Tessler finds that supporting the Islamic political movements does not - necessarily - involve the rejection of. This make sense democracy works a vehicle of bringing politicians through fair competitions, where Islamists have confident of their popularity. Furthermore, Islamic politicians play a clear role in the Middle East; even in secular states (e.g., Turkey, Indonesia, and Tunisia) Islamists find their way to practice politics (Toprak 1981).

In its debate with the secularists' idea of separation of religion and state, Belakziz wrote, "the Islamist discourse considers secularism as a Western philosophy, fitting within the Western historical and religious experience. For this reason, it is not applicable to the socio-political reality in Muslim lands" (2004: 153). Yusuf al-Qaradawi understood secularism in the West as one in which Christianity as a religion does not have a set of norms or laws as fixed as is Sharia law in Islam (1971). Thus, Belakziz argues, Christians may exemplify a separation of church and state with the Biblical admonition "to render unto Caesar what is Caesar's, and to God what is God's" (2004: 377). ${ }^{21}$

One may simply wonder about the feasibility of the idea of the necessary contradiction between secularization and religion. Indeed, they need not be contradictory. Religion is a belief involving piety in practice; secularization is the separation of religious institutions from government institutions with an emphasis on the privatization of religion. In this regard, we might best compare secularism with theocracy rather than religion, as a theocratic government is pursuant to the doctrine of a particular religion as the source of socio-political norms. This clarification helps us to skip the fruitless argument putting secularism in the same field as anti-religion or atheism. Comparing a theocracy to a secular state is a socio-political matter, not a theological one, since religiosity is not

${ }^{21}$ Mark 12:17, New American Standard. 
equal with religion. Religiosity is the human understanding of the religion, not the religion itself. That is to say, those who claim to be enforcing God's law cannot prove - in most of their claims - that they have the absolute truth; indeed, they claim instead the authority of their studies of interpreting the religious text, which may be subject to error as well as accuracy.

There is no single version of theocracy or secularism. The matter of distinction defining the polar ends of our continuum is the source of national norms, laws, and legitimation. On the secular society end of our continuum, we might place such states as the contemporary Scandinavian countries. Moving toward the middle we might position nations such as France, the US, the UK, and Canada (though it is worth noting that the French government has beendespite its claims to the contrary - engaging in religious favouritism). ${ }^{22}$ Further toward the theocratic end of the spectrum would be the UAE, Tunisia, Turkey, and a variety of "Arab Spring" states. This paper, then, deals mostly with Iran and Saudi Arabia. Therefore, when speaking of a "theocracy", this essay refers to Islamic Sharia law; secularism in predominantly Islamic nations will mean irreligious, modern ways of thinking affecting Muslim societies, such as socialism, liberalism, and nationalism.

To this end, Saudi Arabia and Iran are the best cases for studying Muslim theocracy as they have declared their application of Sharia as derived from Islamic text in Sunni and Shia versions, respectively. In this regard, the problem of formal and religious censorship upon individual freedoms is one of the primary topics of debate in the Muslim world, and thus an excellent indicator of where a nation stands in the secular-theocratic continuum.

The strong relationship between state and religion has been mentioned in Arabic heritage. In The Muqaddimah, Ibn Khaldūn (1332-1406) allocated a paper titled "Arabs can obtain royal authority only by making use of some religious colouring, such as prophecy, or sainthood, or some great religious event in general" (Ibn Khaldun 2005: 140, 1958: 305). He argued that Arabs would not subordinate themselves to each other as they have their tribal pride and the intertribal vying of their leaderships. They would therefore respect religious authority as sacred authority. If we consider the historical context of The Muqaddimah - the $14^{\text {th }}$ century-I argue that Ibn Khaldūn means statehood in general, not merely the monarchy. Furthermore, in this period the terms "Arab" and "Muslim" were very close to each other with shared heritage and identity and were almost synonyms; there were virtually no conflicts between them (AlJabiri 1992). Therefore, the theocracy is the most important political concept among Arabs in pre-colonization times.

Salama Moussa (1993) and Zaki Naguib Mahmoud (1971) called for the cutting of national identity from heritage as the best way to modernize Egypt. Such an attitude provoked Islamists, such as al-Qaradawi, who criticized them

\footnotetext{
${ }^{22}$ In France, non-Christians face the ban of wearing religious symbols, including the kippot by Jewish men, hijabs by Muslin women, and turbans by Sikh men in schools. French law claims to establish equality as it bans all symbols, including large Christian cruciform, though Christians still have the right to wear smaller crosses. One may wonder what the state would do if the law were in conflict with the Christian symbols at the same level of the religions of minorities?
} 
and others adopting this attitude; bearing in mind many of those intellectuals who called for modernity, democracy, and following the Western model happened to also be Christian Arabs. Belakziz described this intellectual current as a "secular liberal stream by those who are frankly loyal to Western Culture" (2004: 152).

The aforementioned leads to a discussion of examples of Muslim States and societies in the Middle East. Saudi Arabia represents the theocracy of Sunni Islam and Iran represents the theocracy of Shia Islam. This discussion necessitates each state's structure and impact upon society.

Table 1. The Islamic Ruling in Saudi Arabia and Iran

\begin{tabular}{|l|l|l|l|}
\hline Country & $\begin{array}{c}\text { Muslim } \\
\text { Sect }\end{array}$ & $\begin{array}{c}\text { Religious } \\
\text { Elite }\end{array}$ & \multicolumn{1}{c|}{ Beliefs Regarding wali al-amr } \\
\hline Araudi & Sunni & Wahhabism & $\begin{array}{l}\text { The head of the nation is the Imam "king" who is } \\
\text { accepted by elites OR got the rule by sword and he } \\
\text { does not have to be a cleric. Nobody has right to } \\
\text { challenge him, but if some did and win, he becomes the } \\
\text { new Imam that must be obeyed. }\end{array}$ \\
\hline Iran & Shia & $\begin{array}{l}\text { Vilayat-e } \\
\text { Faqih }\end{array}$ & $\begin{array}{l}\text { The "Absolute Guardianship of the Jurist" means that } \\
\text { the faqih/ Jurist is the guardian who takes care of al } \\
\text { responsibilities and position of Prophet and Twelve } \\
\text { Imams, including governance of the country as the wali } \\
\text { al-amr of the Muslims. The supreme leader must be a } \\
\text { "Faqih" Jurist who is elected by elite of Jurists (clergy } \\
\text { and religious lawyers). }\end{array}$ \\
\hline
\end{tabular}

\section{Saudi Arabia}

Saudi Arabian political model follows the Caliph-Dynasty model of Sunni Islamic state within Islamic civilization history (e.g., Umayyads, Abbasids, and Ottomans). The caliph/ king is the religious leader that everybody must obey and give loyalty. Any challenge to the king is considered as a sin and attempt to temptation. However, if somebody success in defeating the king and taking his place, he automatically becomes the legitimate guardian of 'Muslims' and inherits all features of the position. This model was applied most recently to the Saudi state in 1932 when Ibn Saud unified the territories under his rule, and named the state after his last name - in the same manner of the traditional Islamic Monarchy.

The royal family controls the political and economic spheres of the country. The more you get close to the royal family, the greater your opportunity to gain power. The king is the head of government, and most of the sovereign ministries are headed by royals. The non-royal privileged group is the Najdis and Wahhabis, who belong to the province and religious sect of the royal family. According to Pascal Menoret and Abdullah al-Otaibi (2010: 77-90), the royal family and their entourage (i.e., the powerful families) control economic life in Saudi Arabia. Hence, Saudi citizens are not equal in terms of citizenship level. Thus, economic 
power helps such regimes to privilege their loyal political clientele and award them with continuous elite rotation (Albrecht and Schlumberger 2004).

Browers and Kurzman (2004: 128) cite Western scholars who presented Wahhabism in a positive light, as an Islamic reform movement similar to Lutheran-Protestantism in Christianity. This might well be accurate from a Western perspective, especially given the Wahhabi revolt in the early $20^{\text {th }}$ century against the shared Muslim enemy of the Christian West, the Ottoman Empire. They maintain this favour to the Saudi monarchy goes beyond the objective of defeating that empire, since even the very limited margin of freedom in Saudi Arabia has been seen as positive progress in academic studies. One article that deals with reform in the Arab world considers introducing a written basic code -for the first time in history after 60 years of founding the kingdom- and establishing the Consultative Council (Majlis Al-Shura) this is seen in the same positive light as other Arab reforms, including the parliament elections in other Arab countries. The authors missed that this Consultative Council is fully appointed by the king (Albrecht and Schlumberger 2004).

The Saudi state, which hosts the Muslims' holiest place, insists on being an Islamic state that applies Islamic law-which strengthens Saudi Arabia's image as a country leading the Islamic global struggle against Western attacks on Muslim ethics (Fandy 1999: 3-5). As a result, the religious institutions ${ }^{23}$ invests its efforts to educate people to accept the sacredness of the monarchy through a specific religious doctrine "Wahhabism", including presenting the royal family as the guardian of the Sharia law. Comparing Saudi (Sharia) society with Orthodox Jewish (Talmudic) communities, Souryal (1987) emphasizes that the Saudi society is obsessed with sacredness/ "religion," he argues, "the Sharia [sic] is primarily designed as a moralizing instrument as well as a preventive agent" (Souryal 1987: 432).

Theocracy in Saudi Arabia rejects any secular challenge to the state including elected parliament, or any other serious public participation in the public sphere. Basically, any title other than "true Islam" is also rejected. Mai Yamani (2008) recalls the conflict with the former Egyptian leader Nasser (1918-1970) who also received a strong charismatic among Arab audiences, which threatened other Arab regimes of that time; thus, Saudi monarchy fought Nasser's secular nationalism discourse with a contrasting Islamic-Wahhabi discourse.

\section{Iran}

Iran hosts the second important Shia jurisprudence school in the city of Qum. Thousands of Shia clergy — nationals and immigrants - live within the Iranian territories including a good number of Ayatollahs and the Marja's. ${ }^{24}$ Each of these Marj's is considered by his followers as the deputy of the hidden Imam, and enjoys the position of this Imam, including collecting the religious taxes Khums, issuing fatwas, and teaching the highest level in jurisprudence school.

\footnotetext{
${ }^{23}$ Which is appointed by the king and controlled by the Wahhabi clergy.

${ }^{24}$ They are also called Grand Ayatollahs.
} 
Bearing in mind the large number of those Grand Ayatollahs, the new theocracy created a system to elect an individual Grand Ayatollah to be the Supreme Leader.

Since the monarchy is not legitimated in the Shia jurisprudence, Iranian mullahs employ an old theory of governing called Vilayat-e Faqih, ${ }^{25}$ which translates from Arabic as "the Guardianship of the Islamic Jurists." In this theocratic scheme, the Supreme Leader, Vali-ye faqih, enjoys the authority of the holy $\operatorname{Imam}^{26}$ until the Imam returns, which means the leader has the custodianship over people and they must obey him based on his sacred status, not merely political one. Such a development in Shia Muslim thinking does not reflect the history of the Shia's political history, as they do not believe in an Islamic state without the "Imam" (Nasr 2007). Today, a great number of Shia reject the Islamic-theocratic-state, however, the dominant Iranian clergy have a different view with the system of Vilayat-e Faqih. ${ }^{27}$

The Iranian theocracy is controlled directly by the clergy, a product of Islamic revivalism. In this regard, Hoover argues, the 1979 Iranian revolution synchronizes with the rise of evangelicalism as a political force in North America as "events that seriously confronted prior assumptions about religious reticence, quietude and secularism" (Hoover 2011: 613).

The revolutionary Islamic republic builds a strategy and develops policies to Islamize Iranian society with a focus on the successive attempts to police moral behaviour of young people in public places in the cities (Khatam 2010). Imposing the Hijab, prohibiting alcohol, and out-of-marriage sexual relationships are examples of enforcing authority in the name of Allah in the same manner as the Saudi authorities. However, Iran used to be a Western-style state before the pre-1979 Islamic revolution, which left a portion of the population unsatisfied with such theocratic restrictions. Thus, the Iranian diaspora has increased after the 1979 revolution. In addition, the popularity of the regime depends on the lower economic class; as they tend to support it (Sohrabi-Haghighat 2011). Thus, it is not a surprise to see poor Iranians -the "pious poor"- treat the former president Ahmadinejad like "a rock star" when he visits their poor villages (Peterson 2010: 325).

The Islamic republic tries to integrate the Western democracy with the Shia Islamic theocracy. The highest position -the Supreme Leader- is held by a cleric who is elected by the Assembly of Experts, which is a deliberative body of well-educated Islamic scholars who elect and remove the holder of this position and supervise his activities. The Assembly compromises a body of 86 senior clerics who are responsible for monitoring Iran's supreme leader and choosing his successor" (Rahimi 2007: 287). The membership of the assembly is not a life term; it is in eight-year terms (Ehteshami and Zweiri 2006). On the other hand, the president -who heads the government- is elected for four years'

\footnotetext{
${ }^{25}$ It is pronounced Wilayat al Faqih. in German language, in Persian-Iranian- language "W" is pronounced like "V" in English.

${ }^{26}$ I mentioned earlier to the 12 holy Imams in Shia religion and the $12^{\text {th }}$ "al-Mahdi" one who has been hidden under the rule of Allah and he will come back when Allah lets him.

27 The theory emerged during the Qajar rule by Ahmad Naraqi (1771-1829) who claimed the authority of jurist to be in the same level of the holy prophet and his successors, the 12 Imams.
} 
term, with two terms limit. Here is the integration, the "Supreme Leader," and the "Assembly of Experts" positions are religious and candidates come only from the clergy, while the president and parliament members can come from any background, provided they have no red flags because of their political attitude that is not in accordance with the precepts of an "Islamic" republic.

\section{Conclusion}

Both -Saudi Arabia and Iran- are similar as the state rules with a decidedly religious background, yet they are rather different in terms of type of authority, democratic scale, and historical development. The Kingdom of Saudi Arabia derives its legitimacy from applying Sharia law by a king who has the legitimacy through Bay'ah (the recognition of obedience of the Muslim ruler), while the Islamic Republic of Iran claims its legitimacy via both applying Sharia and an elected authority.

The theological and jurisprudence differences between Sunni and Shia sects play an effective role in legitimating the state structure of each state. Thus, the sectarianism in the Middle East goes beyond theology and salvation matters to be a matter of fighting over legitimacy of the contemporary political affairs. Sectarianism among Muslims today is over the legitimacy of ruling the current states based on sacred texts and historical account, not merely a theological debate over the Islamic history. Such a matter explains the reason behind the current active sectarianism in the Middle East, as politicians utilize religion to legitimize their policies.

Saudi Arabia is an absolute monarchy where the royal family and its close circle monopolize the political and economic spheres in both theory and practice, with no legislative elections. On the other hand, the theocratic-democratic structure of Iran restricts the political sphere for theocratic reasons and their closed circle holds high positions, leaving the other available positions such as non-sovereign ministries and the membership of parliament to public elected officials. However, in theory, all positions - except the Supreme Leader and the membership of Assembly of Experts - are open to all citizens, including nontheocrats. In practice, the loyalty to the Islamic revolution is a considerable feature for candidacy. The economic sphere in Iran has nothing to do with the ideology as the state manages it. Still, corruption in both Saudi Arabia and Iran - as well as neighbouring countries - is high due to the social culture of favouritism in wealthy countries controlled by tight circles of powerful elites power (e.g., royal family, noble tribes, merchants, and clergy) (c.f. Iqbal and Lewis, 2014).

Overall, the modern history of both countries clearly plays a critical role in terms of shaping their Islamist identities in both state and society.

When Ibn Saud started building the kingdom in the early $20^{\text {th }}$ century, the Arabian Peninsula was under the rule of different families (Sheikhdoms) controlling limited territories and following strict patriarchal systems. Thus, the only way to gain power in Arabia during that period was through military force 
led by a strong individual. Such patriarchal rule fits with Weber's model of traditional authority. Just as Saudi families followed the patriarchal system with the father of the family as the highest authority, at the top of the national patriarchal hierarchy are the Saudi rulers. The King is the "father of the nation"whose Islamic title of wali-almr literally means the guardian with authority over his dependents. In Islamic literature, in the case of state affairs, wali-almr is the leader of the Muslim nation; as it is considered normal for the father to control the economic functions of his family-or in the case of a state, its subjects/citizens - and manage the sources of production and distribution. Saudi Arabia is a rentier-economy state. The state owns and controls the natural resources and provides public services such as education, health care, and social security (c.f., Niblock and Malik 2007). In addition, Saudi Arabia is an absolute monarchy that gives the King and his closed circle the full authority to control the enormous wealth coming from oil, helping to keep political power connected to economic power for the Saudi elite. Bearing in mind that Saudi society has never experienced another sort of regimes, thus, any advocacy of democracy would be considered a challenge to the Islamic government.

The Iranian case is different, as the current regime was established in 1979. The country used to be a constitutional monarchy with absolute power residing with the Shah. ${ }^{28}$ The Islamic regime inherited a state that included a parliament and modern/westernized institutions. Thus, regardless of the conservative mullahs' desire, people who revolted over what they called an autocratic regime would not accept an absolute authority holed by an individual. The values of freedom and democracy were such popular slogans in that time that even Khomeini adopted them (Esposito and Voll 1996). Thus, democracy is something beyond an option to the new Islamic Republic, it is an inevitable matter; with giving respect to the Supreme Leader as the wali-almr. Yet theocrats handle the game by controlling the democratic life and filtering the candidates who run to elections. Denying a number of individuals their political rights would not harm the regime, but it keeps the keys of the game in the theocrats' hands.

It may be concluded that democracy, per se, has no place in religious heritage. So, it is instead a contemporary matter for Islamic jurisprudence. In the both cases, the Islamic elite maintain the same manner of the theoretical level of democracy with extending somehow the margin of freedom, like what happens in Iran. For the state with no history of democracy such as Saudi Arabia, the absolute rule is the favored way to govern the state under the conservative Sunni Islamic canopy.

\section{References}

Al-Atawneh M (2009) Is Saudi Arabia a theocracy? Religion and governance in contemporary Saudi Arabia. Middle Eastern Studies 45(5), 721-737.

\footnotetext{
${ }^{28}$ The word Shah in Persian language means King.
} 
Albrecht H, Schlumberger O (2004) "Waiting for Godot": Regime change without democratization in the Middle East. International political science review 25(4): 371-392.

Al-Azmeh A (2008) ilma'nyah men manz'oor mokh'talef [Secularism from a Different Perspective]. Beirut: The Center of Arabic Union Studies.

Al-Banna H (n.d.) majoma'at rasa'il al Imam ash'aheed Hassan al-Banna [The Letter of Imam Hassan al-Banna]. Beirut: The Islamic Institution.

Al-Ghannushi R (1993) al hory'yat al a'amah fi ad'daw'lah al islamiah [The General Freedoms in the Islamic State]. Beirut: The Center of Arabic Union Studies.

Al-Jabiri MA (1992) Mas'alat al hawi'yah [The Matter of Identity]. Beirut: The Center of Arabic Union Studies.

Al-Qaradawi Y (1971) Al holol al mostoradah wa kifa janat alina [The Imported Solutions]. Beirut: al Resalah Institution.

Asad T (2003) Formations of the secular: Christianity, Islam, modernity. Stanford University Press.

Barakat H (1993) The Arab world: Society, culture, and state. University of California Press.

Bayat A (2011) OP-ED: The Sacred and the Secular - Promoting Muslim Democracy. Inter Press Service. Retrieved from http://bit.ly/2jtV75j. [Accessed 14 June 2015].

Belakziz A (2004) Ad'dawlah fi al feker al islami al moa'aser [The State in the Contemporary Islamic Thought]. Beirut: The Center of Arabic Union Studies.

Bhargava R, Acharya A (2008) Political Theory: An Introduction. Pearson Education India.

Blunt WS (2013). The Future of Islam: A New Edition. Routledge.

Browers M, Kurzman C (2004) An Islamic Reformation? Lexington Books.

Ehteshami A, Zweiri M (2006) Understanding Iran's Assembly of Experts. UK: Duringham University.

El-Solh R (1993) Islamist attitudes towards democracy: a review of the ideas of Al-Ghazali, Al-Turabi and Amara. British Journal of Middle Eastern Studies 20(1): 57-63.

Esposito JL (2011) Rethinking Islam and Secularism. Association of Religion Data Archives.

Esposito JL, Voll JO (1996) Islam and democracy. Oxford University Press on Demand.

Fandy M (1999) CyberResistance: Saudi opposition between globalization and localization. Comparative Studies in Society and History 41(01): 124-147.

Federal Research Division (2004) Saudi Arabia: A Country Study. Whitefish Mo: Kessinger Publishing.

Ghazali A H (1960) al-iqtișād fì al-i 'tiquadd. Beirut: Maktabat al-Ḥusayn al-Ṭijārīyah.

Haddad GF (2015) The biographies of the elite lives of the scholars, Imams \& Hadith Masters. Zulfiqar Ayub.

Hirsch ED, Kett JF, Trefil JS (2002) The new dictionary of cultural literacy. Houghton Mifflin Harcourt.

Hoover S M (2011) Media and the imagination of religion in contemporary global culture. European Journal of Cultural Studies, 14(6), 610-625.

Huntington SP (1996). The clash of civilizations and the remaking of world order. New York: Simon and Schuster.

Ibn Khaldun A (2005) Muqaddimah of Ibn Khaldun (intro. by Darwish al- Jawadi). Beirut: Dar al-Kotub al'Assrya.

Ibn Khaldūn (1958) The Muqaddimah: an introduction to history; in three volumes. 1 (no. 43). F Rosenthal, NJ Dawood (Eds.). Princeton University Press. 
Imara M (1987), Almaniyya wa Nahdatuna al-Haditha [Secularism and our modern renaissance]. Cairo: Dar al-Shoroq.

Iqbal Z, Lewis MK (2014) "The Islamic position on corruption." In MK Hassan, MK Lewis (Eds). Handbook on Islam and Economic Life, 283-310. Edward Elgar Publishing.

Jadaane F (1979) osos at'taqadm end mofakeri al islam fi al alalm al araby [The Principles of Progress in the Minds of Islamic Thinkers in the Arab World]. Beirut: The Arabic Institution of Studies and Publication.

Khatam A (2010) Struggling over Defining the Moral City: The Problem Called "Youth" in Urban Iran, 207-224. Being Young and Muslim: New Cultural Politics in the Global South and North.

Lewis B (2010). Faith and power: religion and politics in the Middle East. Oxford University Press.

Luckmann T (1979) The structural conditions of religious consciousness in modern societies. Japanese Journal of Religious Studies, 121-137.

Mahmoud ZN (1971) Tajdeed Al Fiker Al Arabi [Renewal of the Arabic Thought]. Beirut: Dar Ashorooq.

Menoret P, Al-Otaibi A (2010) Rebels without a Cause? A Politics of Deviance in Saudi Arabia, 77-90. Being Young and Muslim: New Cultural Politics in the Global South and North.

Mills C W, Gerth HH (Eds) (1958) From Max Weber: essays in sociology. Oxford University Press.

Moussa S (1993) Mahi'a Al Nahd'dah [What Is Renaissance]. Cairo: General Egyptian Book Organization.

Najjar FM (1996) The debate on Islam and secularism in Egypt. Arab Studies Quarterly 18(2): $1-21$.

Nasr SH (2009) The heart of Islam: Enduring values for humanity. Zondervan.

Nasr V (2007) The Shia revival: How conflicts within Islam will shape the future. WW norton \& Company.

Niblock T, Malik M (2007) The political economy of Saudi Arabia. New York: Routledge.

Norris P, Ronald I (2011) Sacred and secular: Religion and politics worldwide. Cambridge University Press.

Oumlil A (1985) Al Eslahat al Arabiyah wa ad'dawllah al wataniah [The Arabic Reforms and the Nation State]. Casablanca: The Arabic Cultural Center.

Qutb S (1992) Al- mustaqbal hatha ad'din [The Future is for this Religion]. Cairo: Dar Ashorooq.

Peterson S (2010) Let the swords encircle me: Iran-a journey behind the headlines. Simon and Schuster.

Rahimi B (2007) Iran: the 2006 Elections and the Making of Authoritarian Democracy. Nebula 4(1): 285-291.

Rozario S, Samuel G (2011) Introduction to special issue of Contemporary Islam: Islamic piety and gender relationships among contemporary Muslims. Contemporary Islam 5(3): 219-223.

Sohrabi-Haghighat M (2011) New Media and Social-Political Change in Iran. Cyber Orient: Online Journal of the Virtual Middle East 5(1): NN. Retrieved from http://bit.ly/2h6ttag. [Accessed 14 May 2015].

Souryal SS (1987) The religionization of a society: The continuing application of Shariah law in Saudi Arabia. Journal for the Scientific Study of Religion 26(4): 429-449.

Swatos WH, Kivisto P (1998) Encyclopedia of religion and society. Rowman Altamira.

Tamimi A, Esposito JL (2000) Islam and secularism in the Middle East. NYU Press. 
Tessler M (2002) Islam and democracy in the Middle East: The impact of religious orientations on attitudes toward democracy in four Arab countries. Comparative Politics, 337-354.

Toprak B (1981) Islam and political development in Turkey, Vol. 32. Brill.

Wilson S G (1916) Modern movements among moslems. Fleming H. Revell Company.

Yamani M (2008) The two faces of Saudi Arabia. Survival 50(1): 143-156. 